\title{
Analiza stopnia realizacji oczekiwań pacjentów z chorobą nowotworową wobec lekarzy
}

The evaluation of the degree of fulfilment of cancer patients' expectations toward their doctors

\author{
Anna Kornaś ${ }^{1,2} \bowtie$, Barbara Bętkowska-Korpała ${ }^{1}$ \\ ${ }^{1}$ Uniwersytet Jagielloński, Collegium Medicum, Zakład Psychologii Lekarskiej Katedry Psychiatrii, ul. M. Kopernika 21 A, 31-501 Kraków \\ ${ }^{2}$ Szpital Wojewódzki im. św. Łukasza w Tarnowie, Oddział Onkologii Klinicznej z Pododdziałem Chemioterapii, ul. Lwowska 178 A, 33-100 Tarnów \\ $\triangle$ anna.kornas@doctoral.uj.edu.pl
}

\begin{abstract}
Introduction: Oncologically treated patients are a group that requires complementary, multi-disciplinary medical treatment and support. One of the elements of holistic treatment is medical personnel getting to know the patients' expectations.

The main goal of this study was to analyse the expectations that patients with cancer have of their doctors. Two layers of these expectations were assessed - expectations currently being realised, and ideal expectations.

Materials and methods: 107 patients with cancer were qualified to this research. 53 of them received chemotherapy, and 54 radiotherapy. This study was cross-sectional. The research tool was a structured questionnaire which included information on sociodemographic data, about cancer within the closest relatives, and an expectation test prepared by Golzweig et al. Results: In patients' opinion, currently realised expectations were mostly expressive activities: the possibility to trust a doctor
\end{abstract}

( $45 \%$ of patients) and the possibility to talk freely (44\%). The most frequently declared ideal expectations were the possibility to trust a doctor $(67 \%)$ and to have the treatment plan explained (63\%). Ideal expectations were studied with cluster analysis. Two groups were selected. The first of them comprised patients with a higher expectation level $(n=47)$, and the second were patients with a lower expectation level of their doctors $(n=53)$. Higher expectations were essentially more often declared by women, who were $62.5 \%$ of respondents in the first group $(p=0.003)$. An important, monotonic relation was observed between level of education and higher expectations $(p=0.02)$.

Conclusions: Patients treated oncologically expect emotional support and full information about their illness and treatment from their doctors. A higher level of expectations was declared by women, and both sexes with higher education.

Keywords: patients' expectations; physician-patient relations; cancer patients.

\begin{abstract}
ABSTRAKT
Wstęp: Chorzy leczeni onkologicznie są grupą wymagającą komplementarnej, wielospecjalistycznej opieki medycznej oraz zapewnienia wsparcia. Poznanie oczekiwań pacjentów względem personelu medycznego stanowi jeden z elementów holistycznej opieki.

Głównym celem badania była analiza oczekiwań pacjentów z chorobą nowotworową wobec lekarzy. Oczekiwania oceniono na dwóch płaszczyznach - oczekiwań obecnie realizowanych oraz oczekiwań idealnych.

Materiały i metody: Do badania zakwalifikowano 107 pacjentów leczonych z powodu choroby nowotworowej. Chemioterapię otrzymywało 53 chorych, natomiast 54 leczono radioterapią. Badanie miało charakter przekrojowy. Narzędziem badawczym był ustrukturyzowany kwestionariusz zawierający informacje o danych socjodemograficznych, informację o chorobach nowotworowych w najbliższej rodzinie oraz test oczekiwań opracowany przez Goldzweiga i wsp.

Wyniki: W ocenie pacjentów oczekiwaniami obecnie realizowanymi przez lekarzy w najwyższym stopniu były czynności
\end{abstract}

ekspresyjne - możliwości zaufania lekarzowi (45\% chorych) oraz możliwości swobodnej rozmowy (44\%). Do oczekiwań idealnych, deklarowanych w najwyższym stopniu, należała możliwość zaufania lekarzowi (67\%) oraz objaśniania planów leczenia (63\%). Ponadto w ocenie oczekiwań idealnych, metodą analizy skupień, wyodrębniono dwie grupy. Pierwszą grupę stanowili chorzy deklarujący wyższy poziom oczekiwań (n $=47)$, natomiast drugą grupę pacjenci z niższymi oczekiwaniami w stosunku do lekarzy ( $\mathrm{n}=53)$. Wyższy poziom oczekiwań istotnie częściej deklarowały kobiety, które stanowiły 62,5\% badanych w pierwszej grupie $(p=0,003)$. Obserwowano istotną, monotoniczną zależność pomiędzy poziomem wykształcenia a większymi oczekiwaniami $(\mathrm{p}=0,02)$.

Wnioski: Pacjenci leczeni onkologicznie oczekują od lekarzy relacji zapewniającej im wsparcie emocjonalne oraz pełne informowanie na temat choroby i prowadzonego leczenia. Największe oczekiwania deklarują kobiety oraz osoby obu płci z wyższym wykształceniem.

Słowa kluczowe: oczekiwania pacjentów; relacja lekarz-pacjent; pacjent onkologiczny. 


\section{WSTEP}

Począwszy od lat 90. XX w. systematycznie wzrasta zainteresowanie badaczy zagadnieniem potrzeb i oczekiwań pacjentów. Oczekiwania względem personelu medycznego stały się obecnie częstym elementem oceny satysfakcji z korzystanych usług medycznych świadczonych przez podmioty opieki zdrowotnej w celu podniesienia jakości oferowanych świadczeń [1, $2,3]$. Pierwsze, pojedyncze badania nad oczekiwaniami pacjentów prowadzone były w latach 60. XX w. Już wówczas badani jako istotne deklarowali w wyższym stopniu oczekiwanie wsparcia emocjonalnego i informowania niż czynności instrumentalnych $[4,5]$.

Rozwój poszczególnych dziedzin medycyny, nowe metody diagnostyczno-lecznicze, ewolucja relacji lekarz-pacjent czy zmiany w funkcjonowaniu ochrony zdrowia spowodowały odejście od instrumentalizmu na rzecz holistycznej opieki [6]. Istotne stało się poznanie opinii na temat jakości opieki medycznej, potrzeb i oczekiwań chorych. Szczególną grupę w tym ujęciu tworzą pacjenci leczeni z powodu chorób nowotworowych wymagający długotrwałego leczenia i obserwacji, borykający się z objawami choroby, toksycznością terapii oraz koniecznością dostosowania funkcjonowania społecznego do ograniczeń narzuconych przez chorobę. Równolegle obserwowany jest proces unifikacji chorób nowotworowych prowadzący do stygmatyzacji pacjentów onkologicznych. Tymczasem poszczególne typy nowotworów stanowią niejednorodną grupę wymagającą odmiennej diagnostyki i leczenia, mającą różne rokowania oraz w konsekwencji obligującą do zapewnienia indywidualnego wsparcia i opieki nad każdym chorym. Wszystkie te czynniki modulują deklarowane oczekiwania w stosunku do lekarzy.

Po dokonaniu przeglądu bazy Medline oraz Web of Science w celu analizy wyników badań nad oczekiwaniami i potrzebami, które chorzy kierują do lekarzy, można wnioskować, iż badania te prowadzone są najczęściej na grupie pacjentów korzystających ze świadczeń podstawowej opieki zdrowotnej a także pacjentów oddziałów zabiegowych [7]. Nieliczne badania poświęcone są grupie pacjentów z chorobą nowotworową hospitalizowanych w ośrodkach onkologicznych [8].

Przegląd narzędzi wykorzystywanych w badaniach nad oczekiwaniami pacjentów wskazuje na każdorazowo autorskie tworzenie kwestionariuszy, co uniemożliwia odniesienie się do testu referencyjnego, a przez to nie można dokonać pełnej walidacji danego narzędzia. Ogranicza to możliwości interpretacji i porównywania wyników między badaniami.

Badanie poświęcone zagadnieniu oczekiwań pacjentów z chorobą nowotworową wobec lekarzy przeprowadzili Goldzweig i wsp. [9, 10]. Obserwacje prowadzono na grupie 1079 pacjentów. Oczekiwania podzielone zostały na 3 kategorie: wsparcia kognitywnego (informacji oraz wyjaśnienia choroby i leczenia), wsparcia emocjonalnego oraz kontaktu, jaki lekarz nawiązuje z członkami rodziny pacjenta (wsparcie i wyjaśnienia dotyczące choroby dla rodziny). Najwięcej pacjentów oczekiwało zapewnienia możliwości zwrócenia się ze swoimi problemami, swobodnej rozmowy z lekarzem i możliwości zaufania mu. Najrzadziej pacjenci oczekiwali, aby lekarz objaśniał chorobę oraz planowane leczenie ich rodzinie i najbliższym.

Pacjenci z najwyższym poziomem satysfakcji stanowili $16,2 \%$. W grupie tej znalazły się osoby deklarujące, iż obecny stopień zadowolenia z relacji z lekarzem, na wszystkich ocenianych poziomach, odpowiada ich oczekiwaniom.

W tym samym badaniu dodatkowo analizowano wyobrażenia lekarzy onkologów $(n=49)$ na temat oczekiwań pacjentów $\mathrm{z}$ chorobą nowotworową. Zaobserwowano istotną różnicę w postrzeganiu oczekiwań pacjentów przez lekarzy. W ocenie lekarzy pacjenci najczęściej oczekują wyjaśnień dotyczących planowanej terapii oraz dodawania otuchy w czasie leczenia. Natomiast potrzebę możliwości zaufania lekarzowi oraz angażowania chorego w planowanie procesu leczniczego dostrzega mniej niż $1 / 3$ badanych onkologów.

Badanie Goldzweiga i wsp. dotyczące oczekiwań chorych stało się inspiracją do przeprowadzenia analogicznych obserwacji w grupie pacjentów polskich [9, 10].

Głównym celem badania było poznanie oczekiwań pacjentów realizowanych w obecnej sytuacji zdrowotnej, tzw. aktualnych, jak i oczekiwań pożądanych w najwyższym stopniu - tzw. idealnych oraz analiza zgodności pomiędzy realizowanymi oczekiwaniami - aktualnymi a idealnymi.

\section{MATERIAtY I METODY}

\section{Grupa badana}

Do badania zakwalifikowano pacjentów leczonych z powodu choroby nowotworowej $(\mathrm{n}=107)$. Chemioterapię otrzymywało 53 chorych, natomiast 54 leczono radioterapią. Badanie prowadzono w okresie od marca do lipca 2016 r. na Oddziale Onkologii Klinicznej z pododdziałem Chemioterapii oraz na Oddziale Radioterapii Szpitala Wojewódzkiego w Tarnowie. Do badania nie rekrutowano pacjentów z zaburzeniami świadomości, ze zdiagnozowanymi ciężkimi chorobami psychicznymi, deficytami poznawczymi oraz w złym stanie ogólnym (ECOG > 2).

Udziału w badaniu odmówiło 7 (6,5\%) pacjentów - 4 w trakcie radioterapii, $3 \mathrm{w}$ trakcie chemioterapii. Czterech chorych nie podało przyczyny odmowy, 1 z pacjentów odmowę tłumaczył brakiem zmian w opiece zdrowotnej mimo wypełniania kolejnych ankiet i formularzy, kolejnych 2 pytania zawarte w kwestionariuszu oceniło jako zbyt osobiste, ingerujące w prywatność.

Ostatecznie w badaniu analizowano wyniki 100 pacjentów. Średnia wieku badanej grupy wynosiła 61,1 lat (SD 11,86). Strukturę socjodemograficzną opisano w tabeli 1.

\section{Narzędzia i metody}

Przeprowadzone badanie miało charakter przekrojowy. Narzędzie badawcze stanowił 2-częściowy, ustrukturyzowany kwestionariusz, który wypełniany był anonimowo. Pierwsza część zawierała dane socjodemograficzne oraz informację o chorobach nowotworowych w najbliższej rodzinie. W drugiej części wykorzystano test oczekiwań opracowany przez Goldzweiga 
TABELA 1. Struktura społeczno-demograficzna badanej grupy

\begin{tabular}{ll}
\multicolumn{1}{c}{ Zmienna } & $\%$ \\
\hline Płeć & \\
\hline kobiety & 48 \\
\hline mężczyźni & 52 \\
\hline Miejsce zamieszkania & 50 \\
\hline wieś & 21 \\
\hline miasto <50 tys. mieszkańców & 29 \\
\hline miasto >50 tys. mieszkańców & 27 \\
\hline Stan cywilny & 73 \\
\hline samotny/-a & 16 \\
\hline w związku & 48 \\
\hline Wykształcenie & 26 \\
\hline podstawowe/gimnazjalne & 10 \\
\hline zawodowe & \\
\hline średnie & 29 \\
\hline wyższe & \\
\hline
\end{tabular}

TABELA 2. Twierdzenia i pytania zawarte w kwestionariuszu badania oczekiwań pacjentów onkologicznych

\section{Oczekiwania aktualne}

1. Lekarz wyjaśnia

mi planowane leczenie.

2. Mogę zwrócić się do lekarza 2 . z moimi problemami.

Mogę swobodnie rozmawiać 3 . z moim lekarzem.

4. Mogę zaufać swojemu lekarzowi.

\section{Lekarz objaśnia mi moją chorobę.}

6. Lekarz mobilizuje mnie i dodaje mi otuchy.

7. Lekarz wyjaśnia moja chorobę oraz leczenie mojej rodzinie/moim najbliższym.

8. Lekarz angażuje mnie w planowanie mojego leczenia.

\section{Oczekiwania idealne}

1. W jakim stopniu chciałby Pan/ chciałaby Pani, aby lekarz wyjaśniał planowane leczenie?

2. W jakim stopniu chciałby Pan/ chciałaby Pani mieć możliwość zwrócenia się z problemami do swojego lekarza?

W jakim stopniu chciałby Pan/ chciałaby Pani rozmawiać swobodnie z lekarzem?

4. W jakim stopniu chciałby Pan/ chciałaby Pani ufać swojemu lekarzowi?

5. W jakim stopniu chciałby Pan/ chciałaby Pani, aby lekarz objaśniał Pana/Pani chorobę?

6. W jakim stopniu chciałby Pan/ chciałaby Pani, aby lekarz dodawat Panu/Pani otuchy?

7. W jaki stopniu chciałby Pan/ chciałaby Pani, aby lekarz wyjaśniał chorobę i leczenie rodzinie/najbliższym?

8. W jakim stopniu chciałaby Pan/chciałaby Pani, aby lekarz angażował Pana/Panią w planowanie leczenia?

4-stopniowa skala odpowiedzi: 1. W ogóle/raczej nie. 2. W niewielkim stopniu. 3. W dużym stopniu. 4. W bardzo dużym stopniu

i wsp. $[9,10]$. Po uzyskaniu zgody autorów przetłumaczono i przeprowadzono adaptację testu dla populacji pacjentów polskich. Kwestionariusz przeznaczony jest do samodzielnego wypełnienia. Badany ustosunkowuje się do 8 twierdzeń. Każde z twierdzeń analizowane jest na dwóch płaszczyznach aktualnej i idealnej. W pierwszej kolejności pacjenci oceniają, $\mathrm{w}$ jakim stopniu realizowane jest dane oczekiwanie - aktualnie, natomiast w drugiej wyobrażenie o najwyższym stopniu spełnienia oczekiwań przez lekarza - idealnie. Odpowiedzi udzielane są na 4-stopniowej skali likertowskiej (1 - w ogólne/raczej nie; 2 - w niewielkim stopniu; 3 - w dużym stopniu; 4 - w bardzo dużym stopniu). Treść poszczególnych itemów przedstawiono w tabeli 2 . Zaletą testu jest jego prosta konstrukcja i niewielka liczba pytań. Żaden $\mathrm{z}$ badanych nie zgłaszał trudności $\mathrm{z}$ interpretacją poleceń zawartych $\mathrm{w}$ formularzu.

\section{Analiza statystyczna}

Rozkład zmiennych jakościowych został opisany poprzez podanie częstości bezwzględnych i względnych, natomiast zmiennej ilościowej poprzez wartość średnią oraz odchylenie standardowe. Dwuetapowa analiza skupień została zastosowana w celu wyodrębniania jednorodnych podzbiorów obiektów badanej populacji. Pozwoliła ona uwzględnić zarówno zmienne ilościowe, jak i jakościowe. Algorytm składa się z dwóch części: pierwszej - wstępnej, mającej na celu utworzenie roboczych podgrup oraz drugiej - mającej na celu utworzenie wielu roboczych podgrup (obiekty jednorodne w obrębie podgrupy). Następnie wykonano analizę skupień na już wyodrębnionych podgrupach. Weryfikacja spójności i odrębności wyodrębnionych grup została oceniona za pomocą współczynnika silhouette (s(i)), który przyjmuje wartości pomiędzy -1 a 1. Wartość powyżej 0,5 świadczy o silnej spójności i odrębności skupień, pomiędzy 0,5 a 0,2 - o poprawnej, natomiast poniżej 0,2 - o słabej strukturze skupień [11]. Do zbadania związku pomiędzy cechami socjodemograficznymi a satysfakcją oraz analizowanymi grupami użyto testu $\chi^{2}$ lub dokładnego testu Fishera w przypadku niespełnienia założeń testu $\chi^{2}$. W przypadku zmiennej wykształcenie zastosowano test dla trendu [12]. Analizy wykonano za pomocą programu SPSS ver. 22. Jako poziom istności przyjęto $\alpha=0,05$ dla testów 2-stronnych.

\section{WYNIKI}

\section{Rzetelność testu}

Kwestionariusz badania oczekiwań pacjentów cechował się wysoką spójnością wewnętrzną. Współczynnik alfa Cronbacha wyniósł 0,904 dla itemów oceniających poziom oczekiwań aktualnie realizowanych oraz 0,828 dla itemów opisujących oczekiwania idealne.

\section{Oczekiwania i poziom ich spełnienia}

Zastosowanie 4-stopniowej skali odpowiedzi, pozbawionej punktu środkowego, na której dwie pierwsze odpowiedzi kierują się w stronę negatywną, a dwie kolejne pozytywnie, obligowało badanych do jednoznacznego opowiedzenia się, nie dając wyboru neutralnego. Najwięcej odpowiedzi mieściło się w zakresie pozytywnym, zarówno dla oczekiwań aktualnych, jak i idealnych. Rozkład odpowiedzi na poszczególne twierdzenia i pytania testu zmieszczono w tabeli 3.

W opinii pacjentów oczekiwaniami aktualnie realizowanymi przez lekarzy w najwyższym stopniu były czynności ekspresyjne. Możliwość zaufania lekarzowi i możliwość swobodnej 
TABELA 3. Rozkład odpowiedzi dla poszczególnych twierdzeń testu oczekiwań pacjentów

\begin{tabular}{|c|c|c|c|c|c|c|c|}
\hline $\begin{array}{l}\text { Twierdzenie/ } \\
\text { Pytanie }\end{array}$ & Oczekiwania & $\begin{array}{l}\text { W ogóle/ } \\
\text { Raczej nie } \\
(\%)\end{array}$ & $\begin{array}{l}\text { W niewielkim } \\
\text { stopniu } \\
(\%)\end{array}$ & $\begin{array}{l}\text { W dużym } \\
\text { stopniu } \\
(\%)\end{array}$ & $\begin{array}{l}\text { W bardzo dużym } \\
\text { stopniu } \\
(\%)\end{array}$ & $\begin{array}{l}\text { Wysoka zgodność } \\
\text { (aktualne = idealne) }\end{array}$ & $95 \% \mathrm{Cl}$ \\
\hline \multirow{2}{*}{1} & aktualne & 2 & 10 & 53 & 35 & \multirow{2}{*}{62} & \multirow{2}{*}{$52,5-71,25$} \\
\hline & idealne & 0 & 2 & 35 & 63 & & \\
\hline \multirow{2}{*}{2} & aktualne & 1 & 6 & 55 & 38 & \multirow{2}{*}{65} & \multirow{2}{*}{$55,7-74,4$} \\
\hline & idealne & 1 & 1 & 40 & 58 & & \\
\hline \multirow{2}{*}{3} & aktualne & 1 & 7 & 48 & 44 & \multirow{2}{*}{62} & \multirow{2}{*}{$52,5-71,25$} \\
\hline & idealne & 0 & 1 & 42 & 57 & & \\
\hline \multirow{2}{*}{4} & aktualne & 0 & 5 & 50 & 45 & \multirow{2}{*}{73} & \multirow{2}{*}{$64,3-81,7$} \\
\hline & idealne & 0 & 0 & 33 & 67 & & \\
\hline \multirow{2}{*}{5} & aktualne & 1 & 13 & 55 & 31 & \multirow{2}{*}{60} & \multirow{2}{*}{$50,4-69,6$} \\
\hline & idealne & 0 & 2 & 40 & 58 & & \\
\hline 6 & idealne & 1 & 2 & 42 & 55 & 62 & $52,5-71,25$ \\
\hline \multirow{2}{*}{7} & aktualne & 8 & 14 & 47 & 31 & \multirow{2}{*}{59} & \multirow{2}{*}{$49,4-68,6$} \\
\hline & idealne & 4 & 8 & 39 & 49 & & \\
\hline \multirow{2}{*}{8} & aktualne & 2 & 13 & 51 & 34 & \multirow{2}{*}{65} & \multirow{2}{*}{$55,7-74,4$} \\
\hline & idealne & 0 & 1 & 41 & 58 & & \\
\hline
\end{tabular}

rozmowy deklarowało odpowiednio 45\% i 44\% badanych. Najniższy poziom realizacji oczekiwań obserwowano dla pytań o stopień objaśniania choroby samemu pacjentowi oraz jego rodzinie.

Jednocześnie pacjenci, w kontekście idealnej relacji, w bardzo dużym stopniu oczekiwali możliwości zaufania lekarzowi (67\%) oraz objaśniania planów leczenia (63\%). Istotne jest zatem dla chorych uczestniczących w badaniu zarówno wsparcie emocjonalne, jak i rzeczowe informowanie. W najmniejszym stopniu pacjenci oczekiwali od lekarza wyjaśnień dotyczących choroby i jej leczenia udzielanych rodzinie i najbliższym (49\%).

Obserwowano wysoki poziom zgodności pomiędzy oczekiwaniami aktualnymi a idealnymi (za autorami testu oczekiwań pacjentów $[9,10]$ - realizowane aktualnie = idealne). Tak samo odpowiedziało $33 \%$ badanych na wszystkie twierdzenia o aktualnie realizowane oczekiwania i pytania o oczekiwania pożądane w najwyższym stopniu. Analizując rozkład odpowiedzi w poszczególnych twierdzeniach, zaobserwowano najwyższy odsetek zgodnych odpowiedzi dla możliwość zaufania lekarzowi (73\%), możliwości zwrócenia się z problemami do lekarza (65\%) oraz angażowania chorych w plany lecznicze $(65 \%)$. Najmniej zgodnych odpowiedzi zanotowano dla potrzeby udzielania informacji przez lekarzy rodzinie i najbliższym pacjenta (59\%).

\section{Analiza klasterowa oczekiwań}

W toku oceny oczekiwań idealnych pacjentów metodą analizy skupień wyodrębniono dwie grupy. Miarę spójności i odrębności określono jako dobrą s(i) = 0,55. Pierwszą grupę stanowili chorzy deklarujący wyższy poziom oczekiwań $(n=47)$, natomiast drugą grupę pacjenci z niższymi oczekiwaniami w stosunku do lekarzy ( $\mathrm{n}=53$ ). Największy wpływ na wyodrębnienie skupień okazało się mieć pytanie o możliwość swobodnej rozmowy z lekarzem. Rozkład odpowiedzi na poszczególne pytania, którym badani przypisali najwyższą wartość punktową (w bardzo dużym stopniu) w obu grupach, przedstawiono na rycinie 1 . Średnia wieku w pierwszej i drugiej grupie wynosiła odpowiednio 59,9 (SD 11,87) lat vs $62,2(S D 11,86)$ lat $(p=0,3)$. Wyższy poziom oczekiwań istotnie częściej deklarowały kobiety, które stanowiły 62,5\% badanych $\mathrm{w}$ pierwszej grupie $(\mathrm{p}=0,003)$. Obserwowano istotną, monotoniczną zależność pomiędzy poziomem wykształcenia a wyższymi oczekiwaniami $(\mathrm{p}=0,02)$. Wraz ze wzrostem poziomu wykształcenia rósł odsetek chorych deklarujących wyższe oczekiwania w stosunku do lekarzy. Wielkość miejsca zamieszkania, stan cywilny uczestników badania, wstępowanie chorób nowotworowych w rodzinie nie różniły się między wyodrębnionymi grupami (tab. 4).

Analizę skupień przeprowadzono także dla twierdzeń o aktualnie realizowanych oczekiwaniach. Podobnie jak w przypadku oczekiwań idealnych, wyodrębniono dwie grupy. Miara spójności i odrębności wynosiła s(i) = 0,51. Najistotniej

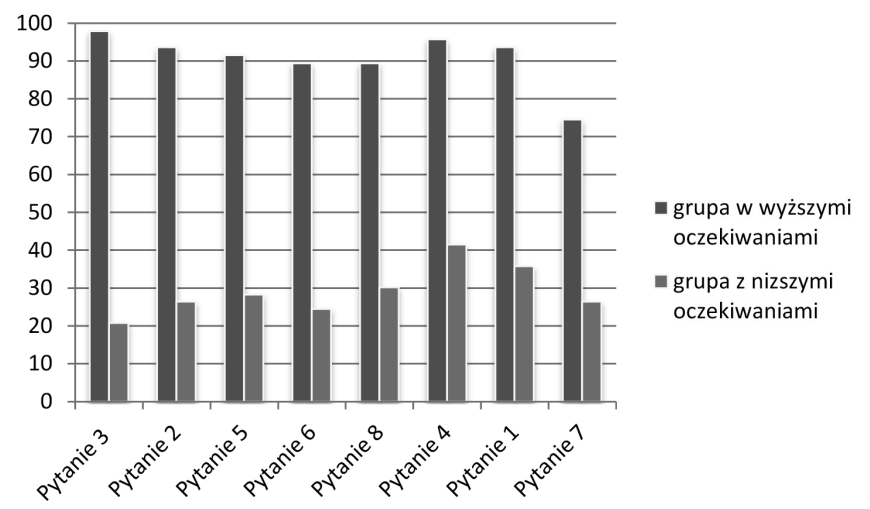

RYCINA 1. Analiza klasterowa oczekiwań idealnych - rozkład odsetkowy odpowiedzi najwyższych w poszczególnych skupieniach 
TABELA 4. Porównanie skupień oczekiwań idealnych pod względem zmiennych socjodemograficznych

\begin{tabular}{|c|c|c|c|c|c|}
\hline \multirow{2}{*}{ Zmienna socjodemograficzna } & \multicolumn{2}{|c|}{ Grupa z wyższymi oczekiwaniami } & \multicolumn{2}{|c|}{ Grupa z niższymi oczekiwaniami } & \multirow{2}{*}{$\mathbf{p}$} \\
\hline & $\mathrm{n}$ & $\%$ & $\mathrm{n}$ & $\%$ & \\
\hline \multicolumn{6}{|l|}{ Płeć } \\
\hline kobiety & 30 & 62,5 & 18 & 37,5 & \multirow{2}{*}{0,003} \\
\hline mężczyźni & 17 & 32,7 & 35 & 67,3 & \\
\hline \multicolumn{6}{|l|}{ Miejsce zamieszkania } \\
\hline miasto $<50$ tys. mieszkańców & 9 & 42,9 & 12 & 57,1 & \multirow[t]{2}{*}{0,15} \\
\hline miasto >50 tys. mieszkańców & 18 & 62,1 & 11 & 37,9 & \\
\hline \multicolumn{6}{|l|}{ Stan cywilny } \\
\hline związek & 32 & 43,8 & 41 & 56,2 & \multirow{2}{*}{0,3} \\
\hline samotny/-a & 15 & 55,6 & 12 & 44,4 & \\
\hline podstawowe/gimnazjalne & 5 & 31,3 & 11 & 68,7 & \multirow{4}{*}{0,02} \\
\hline zawodowe & 21 & 43,8 & 27 & 56,2 & \\
\hline średnie & 13 & 50 & 13 & 50 & \\
\hline wyższe & 8 & 80 & 2 & 20 & \\
\hline \multicolumn{6}{|l|}{ Nowotwór w rodzinie } \\
\hline tak & 27 & 46,6 & 31 & 53,4 & \multirow{2}{*}{0,916} \\
\hline nie & 20 & 47,6 & 22 & 52,4 & \\
\hline
\end{tabular}

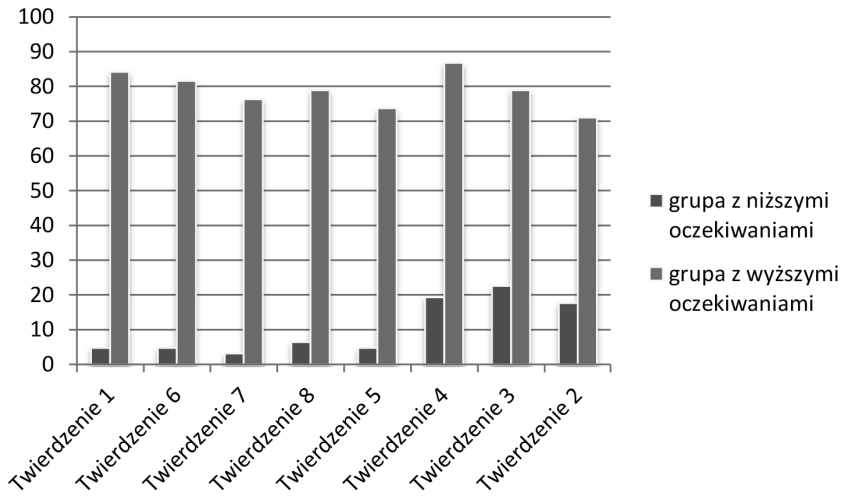

RYCINA 2. Analiza klasterowa oczekiwań aktualnych - rozkład odsetkowy odpowiedzi najwyższych w poszczególnych skupieniach

różnicującymi były pytania o wyjaśnienie leczenia oraz wyjaśnienia o chorobie przekazywane rodzinie i najbliższym (ryc. 2). Nie zaobserwowano jednak istotnej różnicy między grupami w zakresie cech socjodemograficznych a występowaniem nowotworu w rodzinie (tab. 5).

\section{DYSKUSJA}

Zaprezentowany kwestionariusz badania oczekiwań realizowanych aktualnie i idealnych wobec braku powszechnie stosowanych testów stanowi alternatywę dla autorskich narzędzi. Oprócz poznania oczekiwań pacjentów umożliwia ocenę satysfakcji z ich realizacji. Dzięki prostej konstrukcji pozwala pacjentom na trafne i szybkie udzielenie odpowiedzi, a badaczowi nie stwarza problemów interpretacyjnych.
Rozkład odpowiedzi pacjentów zaprezentowanego badania odpowiada wynikom uzyskanym przez Goldzweiga i wsp. $[9,10]$. Polscy pacjenci deklarują wyższy stopień realizacji oczekiwań (wysoka zgodność oczekiwań aktualnie realizowanych i idealnych $=33 \%$ ). Analizę wyników poszerzono o wyodrębnienie klasterów w zakresie deklarowanych oczekiwań. Pozwoliło to na wyróżnienie grup o wyższych oczekiwaniach - kobiety, osoby z wyższym wykształceniem - co stanowi sugestię dla lekarzy co do zapewnienia spersonalizowanej opieki warunkującej uzyskanie satysfakcji z oferowanych usług.

W Polsce ogólnodostępnym narzędziem badającym oczekiwania wobec lekarzy jest Lista Oczekiwań Pacjenta (PRF) autorów Salmon i Quine w adaptacji Juczyńskiego [13]. Wyodrębnia ona 3 kategorie oczekiwań: wyjaśnienie choroby, wsparcie oraz uzyskanie informacji na temat wyników badań i leczenia. Narzędzie to bada jednak relację między pacjentami a lekarzami ogólnymi/rodzinnymi. Porusza aspekty podstawowej opieki zdrowotnej, takie jak oczekiwanie skierowania do specjalisty lub przeprowadzenia szczegółowej diagnostyki. Brakuje natomiast zwalidowanego narzędzia przeznaczonego dla chorych pozostających w lecznictwie stacjonarnym.

Badanie oczekiwań pacjentów onkologicznych autorskim kwestionariuszem, inspirowanym testem PRF, przeprowadziła Zieniuk w Centrum Onkologii - Instytucie im. M. Skłodowskiej-Curie w Warszawie [14]. Kwestionariusz badania, oprócz elementów oceny wsparcia emocjonalnego, informowania i wyjaśniania, zawierał również elementy oceniające oczekiwane czynności instrumentalne od personelu medycznego. To właśnie aspekty informowania oraz umiejętności instrumentalne były najistotniejsze dla pacjentów objętych badaniem.

Na oczekiwania wsparcia i informowania zwracają również uwagę Cieślak i wsp. w badaniu analizującym relację między 
TABELA 5. Porównanie skupień oczekiwań aktualnych pod względem zmiennych socjodemograficznych

\begin{tabular}{|c|c|c|c|c|c|}
\hline \multirow{2}{*}{ Zmienna socjodemograficzna } & \multicolumn{2}{|c|}{ Grupa z wyższymi oczekiwaniami } & \multicolumn{2}{|c|}{ Grupa z niższymi oczekiwaniami } & \multirow{2}{*}{$\mathbf{p}$} \\
\hline & $\mathrm{n}$ & $\%$ & $\mathrm{n}$ & $\%$ & \\
\hline \multicolumn{6}{|l|}{ Płeć } \\
\hline kobiety & 21 & 43,8 & 27 & 56,3 & \multirow{2}{*}{0,3} \\
\hline mężczyźni & 17 & 32,7 & 35 & 67,3 & \\
\hline \multicolumn{6}{|l|}{ Miejsce zamieszkania } \\
\hline wieś & 20 & 40 & 30 & 60 & \multirow{3}{*}{0,6} \\
\hline miasto $<50$ tys. mieszkańców & 6 & 28,6 & 15 & 71,4 & \\
\hline miasto $>50$ tys. mieszkańców & 12 & 41,4 & 17 & 58,6 & \\
\hline \multicolumn{6}{|l|}{ Stan cywilny } \\
\hline związek & 27 & 37 & 46 & 63 & \multirow{2}{*}{0,7} \\
\hline samotny/-a & 11 & 40,7 & 16 & 59,3 & \\
\hline \multicolumn{6}{|l|}{ Wykształcenie } \\
\hline podstawowe/gimnazjalne & 8 & 50 & 8 & 50 & \multirow{4}{*}{0,7} \\
\hline zawodowe & 18 & 37,5 & 30 & 62,5 & \\
\hline średnie & 8 & 30,8 & 18 & 69,2 & \\
\hline wyższe & 4 & 40 & 6 & 60 & \\
\hline \multicolumn{6}{|l|}{ Nowotwór w rodzinie } \\
\hline tak & 19 & 32,8 & 39 & 67,2 & \multirow{2}{*}{0,2} \\
\hline nie & 19 & 45,2 & 23 & 54,8 & \\
\hline
\end{tabular}

typem radzenia sobie z chorobą nowotworową a deklarowanymi potrzebami [15].

Wyniki każdego z przytoczonych badań wskazują na potrzebę skutecznej komunikacji, dodawania otuchy i czynności ekspresyjnych jako istotnych aspektów budowania relacji lekarz-pacjent. Dodatkowo w prezentowanym w niniejszej publikacji badaniu własnym analizowano problem informowania rodziny o stanie zdrowia i prowadzonym leczeniu, nieporuszony w żadnym z przytoczonych wcześniej badań polskich. Zwraca uwagę najniższy odsetek odpowiedzi pozytywnych dla tego zagadnienia. Fakt ten można tłumaczyć chęcią ochrony bliskich osób przed trudną diagnozą czy niepomyślnym rokowaniem.

Poznanie i realizacja oczekiwań chorych jest istotnym elementem w budowaniu dobrej relacji, w tym skutecznej komunikacji między lekarzem a pacjentem. Wpływa ona na realizację zaleceń lekarskich przez pacjentów, a przez to w pośredni sposób determinuje skuteczność terapii [16, 17]. Analizy oczekiwań pacjentów z chorobą nowotworową powinny być rozszerzane i prowadzone wieloaspektowo. Umożliwi to opracowanie metodologii prowadzenia badań w tym zakresie oraz porównywanie wyników między badaniami.

\section{WNIOSKI}

1. Pacjenci leczeni onkologicznie oczekują od lekarzy zapewnienia wsparcia emocjonalnego oraz rzeczowego informowania. Wśród analizowanych oczekiwań najważniejszymi dla pacjentów były czynności ekspresyjne: możliwość zaufania oraz możliwość swobodnej rozmowy. W mniejszym stopniu chorzy oczekiwali wyjaśnień dotyczących choroby i leczenia udzielanych rodzinie.

2. Najwyższy odsetek zgodnych odpowiedzi dla oczekiwań aktualnych oraz idealnych zaobserwowano w 3 kategoriach: zaufania lekarzowi, możliwości zwrócenia się z problemami do lekarza oraz angażowania chorych w plany lecznicze.

3. Wyższe oczekiwania w stosunku do lekarzy deklarują kobiety oraz pacjenci obu płci z wyższym wykształceniem.

\section{PIŚMIENNICTWO}

1. Ware JE Jr, Snyder MK, Wright WR, Davies AR. Defining and measuring patient satisfaction with medical care. Eval Program Plann 1983;6:247-63.

2. Licina P, Johnston M, Ewing L, Mark P. Patient expectations, outcomes and satisfaction: related, relevant or redundant? Evid Based Spine Care J 2012;3(4):13-9. doi: 10.1055/s-0032-1328138.

3. Kurpas D, Steciwko A. Satysfakcja pacjenta jako główny wskaźnik poziomu jakości podstawowej opieki zdrowotnej. Przegl Lek 2005;62(12):1546-51.

4. Izrael J. Socjopsychiczne środowisko szpitala. In: Sokołowska M, editor. Badania socjologiczne w medycynie. Warszawa: Książka i Wiedza; 1969.

5. Korsch BM, Gozzi EK, Francis V. Gaps in doctor-patient communication. Doctor-patient interaction and patient satisfaction. Pediatrics 1968;42(5):855-71.

6. Bętkowska-Korpała B, Gierowski JK. Psychologia lekarska a profesjonalny kontakt lekarza z pacjentem. In: Bętkowska-Korpała B, Gierowski JK, editors. Psychologia lekarska w leczeniu chorych somatycznie. Kraków: Wydawnictwo Uniwersytetu Jagiellońskiego; 2007. p. 7-15.

7. Bowling A, Rowe G, Lambert N, Waddington M, Mahtani KR, Kenten C, et al. The measurement of patients' expectations for health care: a review and psychometric testing of a measure of patients expectations. Health Technol Assess 2012;16(30): i-xii,1-509. doi: 10.3310/hta16300.

8. Kornaś A, Bętkowska-Korpała B. Oczekiwania pacjentów onkologicznych wobec lekarzy. Przegl Lek 2016;73(11):841-4.

9. Goldzweig G, Meirovitz A, Hubert A, Brenner B, Walach N, Perry S, et al. Meeting expectations of patients with cancer: relationship between patient satisfaction, depression, and coping. J Clin Oncol 2010;28(9):1560-5. 
10. Goldzweig G, Abramovitch A, Brenner B, Perry S, Peretz T, Baider L, et al Expectations and level of satisfaction of patients and their physicians: concordance and discrepancies. Psychosomatics 2015;50(5):521-9.

11. Chiu T, Fang D, Chen J, Wang Y, Jeris C. A robust and scalable clustering algorithm for mixed type attributes in large database environment. In: Proc 2001 Int Conf on Knowledge Discovery and Data Mining (KDD’01). San Francisco (CA); 2001. p 263-8.

12. Agresti A. An introduction to categorical data analysis. 2nd ed. John Wiley \& Sons; 2007. doi: 10.1002/0470114754.

13. Juczyński Z. Narzędzia pomiaru w promocji i psychologii zdrowia. War szawa: Pracownia Testów Psychologicznych Polskiego Towarzystwa Psychologicznego; 2001.
14. Zieniuk A. Oczekiwania pacjenta onkologicznego wobec personelu medycznego. Psychoonkologia 2009;1-2:17-27.

15. Cieślak K, Pawlukiewicz M, Gołąb D, Konys M, Kuśnierkiewicz M, Kleka P. Styles of coping with stress of cancer in patients treated with radiotherapy and expectations towards medical staff - Practical implications. Rep Pract Oncol Radiother 2013;18(2):61-6. doi: 10.1016/j.rpor.2012.10.006.

16. Cramer JA. Effect of partial compliance on cardiovascular medication effectiveness. Heart 2002;88(2):203-6.

17. Britten N, Stevenson FA, Barry CA, Barber N, Bradley CP. Misunderstandings in prescribing decisions in general practice: qualitative study. BMJ 2000;320(7233):484-8. 